\title{
The Meanings of the Death of the Founder: The Constructionist Approach
}

\author{
Mozar José de Brito * \\ E-mail address: mozarjdb@dae.ufla.br \\ Universidade Federal de Lavras - PPGAD/UFLA \\ Lavras, MG, Brazil.
}

\section{Sabrina Soares da Silva}

E-mail address: sabrina.silva@unifal-mg.edu.br Universidade Federal de Lavras - UFLA

Lavras, MG, Brazil.

\section{Mayara Maria de Jesus Muniz}

E-mail address: mayaramunizadm@hotmail.com

Universidade do Estado da Bahia - UNEB

Santo Antonio de Jesus, BA, Brazil.

\section{ABSTRACT}

The aim of this article is to investigate the meanings constructed around the death of a university center's founder. For this purpose, the culture theory and the social constructionism approach formed the theoreticalmethodological basis. In this qualitative descriptive research, the triangulation of various data collection techniques was utilized and an analysis of the discursive practices was conducted. The reflections presented in this article could serve as a starting point for other researchers who are interested in investigating and constructing new theoretical and methodological reflections on this subject, which is absent from the theory of organizations. If this is the case, the researchers should bear in mind that the death of the founder of any organization takes on meanings that lie on the frontiers between the subjectivity of people and the organizational culture. The death of the founder, in any organization, cannot and should not be studied as something natural to those who have lost their historical reference, incorporating the figure of the hero, embellished with all his symbolism.

Key words: social constructionism; organizational culture; foundation myth.

Received 17 February 2009; received in revised form 20 October 2009.

Copyright (C) 2010 Brazilian Administration Review. All rights reserved, including rights for translation. Parts of this work may be quoted without prior knowledge on the condition that the source is identified.

\footnotetext{
* Corresponding author: Mozar José de Brito

UFLA, Campus Universitário, Caixa Postal 3037, Lavras, MG, 37200-000, Brazil.
} 


\section{INTRODUCTION}

Death and its material and symbolic implications have not been the object of analysis in Brazilian organizational studies. Therefore, despite the social relevance of this critical event for organizations and the questions associated with it, theoreticians in administration have not prepared explanatory systems or theoretical and methodological formulations concerning the meanings of the death of a founder or certain leading figures and the organization itself. From an academic viewpoint, this matter should and must be explored since it is a social phenomenon that is significant to the culture and other significant dimensions of organizational life. It is an event which, besides being a biological end of a life, is a reference that leads to other social and symbolic repercussions.

The death of a founder may or may not mean a breakaway from the past and the beginning of an institutionalization process for a new organizational order that will result in different meanings in the minds of members of the organization and the family that controls it. This social fact influences organizational life in its objective and subjective dimensions. Therefore, death is not merely the fact that life has ceased; on the contrary, it is deeply embedded in a symbolic universe that is based on cultural patterns being constructed within the organization. In other words, interpretations of this social fact will always be the result of human subjectivity, the carriers of meanings anchored in a set of organizational values and other cultural elements.

The aim of this article in the field of organizational analysis is to investigate the meanings surrounding the death of the founder of a university center. For this purpose, a theoreticalmethodological approach has been used that includes the notion of organizational culture, myths, feelings about death and some reflections on social constructionism, the ontological and epistemological assumptions of which have served as a basis for understanding the phenomenon.

\section{Organizational Culture, Foundation Myth and the Meanings of Death}

This study required a multifaceted theoretical foundation. As a result, it was necessary to refer to theoretical constructs and complementary reflections that helped configure a reference framework to support the analytical effort of the meanings constructed around the death of the founder under study.

\section{Organizational Culture: the Many Facets of the Production of a Concept}

Brazilian and international literature in administration deals with the most different analysis perspectives of organizational culture. Amid this analytical plurality, the origins of which lie in anthropological tradition, there is no theoretical and methodological consensus. The aim is to examine some theoretical reflections on the concept and examine the notion of the founder myth as a constitutive element in the culture of organizations.

In the field of organizational analysis, several studies have sought to reinterpret classic conceptions, bringing a more dynamic and comprehensive vision to the theory of organizations (Aktouf 1993; Carrieri, 2002; Fleury \& Fisher, 1996; Rodrigues, 1997). Among these studies, there are some that stand out, those that sought to provide explanations concerning the symbolic universe of organizations. According to Jeffcutt (1993, 1994a, 1994b), debates about organizational culture and symbolism have led to different styles of interpretation that are often diverging or contradictory. On the one hand are the narratives that express a type of recurring managerialism. From this viewpoint, culture has been approached as an organizational possession, a stable symbolic system, definitive and hierarchical. The culture, in this case, is in the hands of the administration, being approached as an expression of authority, a symbolic glue that preserves integration and controls any disintegrating and dysfunctional sources in the organization. On the other hand are the narratives that express critical 
humanism. Culture is theorized as a creative expression of the members of an organization, an amorphous, passing and symbolic process. Organizational culture is theorized as a network of socially constructed meanings whose main function is to mediate conflicts of interest and create a negotiated order.

This study began under the assumption that organizations are socially constructed organized activities. This choice requires the examination of some conceptual matters that are found in the different narratives: (1) singularity of organizational cultures and (2) the objective and subjective dimensions of organizational culture. The notion of organizational culture leads us back to the idea of identity, of distinction, those characteristics that bring a uniqueness to organizations and make them different from one another. Some studies have shown that the formulation of strategies and the organization of the work process, among other important aspects of organizational life, are reflections of the specific culture of the organization in question. The objective dimension of organizational culture is the visible artifacts created by the organization. It is the most emerging manifestation of organizational culture. In this dimension, the cultural expressions are easily observed but difficult to interpret in their real significations (Schein, 1992). The subjective dimension of organizational culture involves the symbolic universe constructed by the historically and socially constituted subjects. This dimension involves the meanings attributed to the organization's cultural production, including the myths, heroes, rites, rituals, legends, folklore, values, basic assumptions and organizational beliefs. Bourdieu (1991), when considering these dimensions, defines culture as being an expression of meanings that are constructed, maintained, taught and modified by social actors, and also as a structure as it is objectified through social practices. For this study, the aforementioned concept will be adopted along with the opinions of some authors on the foundation myth and the meaning of death.

\section{Foundation Myth and the Meaning of Death}

From the theories referred to in this study, organizational culture could be unveiled by taking into consideration the meaning attributed to the elements that constitute it (Schultz, 2004). Among the constitutive elements of the culture of an organization are the material artifacts, values, symbols, rites, rituals, stories and myths. For this study, attention has been focused on the concept of myth by judging that the formulations of symbolic anthropology concerning this analytical category will be useful in order to understand the meanings produced by the death of the founder of the organization in question.

According to Tavares (1991, p. 76), myth can be defined as "a verbal expression (written or oral) that exposes the vision of the world, norms of socially acceptable actions and socially selected purposes (values), establishing pertinent models of thinking/acting/feeling (their own) for a certain social group”. It is a significant analytical category for researching the socially constructed symbolic universe in organizational space. It is the expression of culture that represents the link between the present and the past (Eliade, 1999). To this author, the myth would be a sacred story that tells of an event that took place in the early days, the fabled time of the "beginning". In other words, the myth tells how a reality came to exist. The myth, as a cultural element, provides an explanation, meaning and legitimacy for a reality from the outset. According to Eliade (1999), the myth refers to the social imagination, to the origins as a form of restarting the past, a sort of eternal journey back in time to the days of the foundation. Symbolically, people seek to return to the past in an attempt, albeit impossible, to become similar to the heroes of the foundation in spite of their mortality.

The temporality of the myth appears to be the converging point of the various conceptual formulations put forward by different authors. According to Barthes (1989), the myth is a communication system, a "semiological system" that acts as a reference to the collective production of meanings. It is a symbolic construction that can be reproduced and passed down for several generations. It also circumscribes and sets in place a relevant event for the members of a group, organization or community. It would be a narrative of the creation, a true story that reveals how something, which never was, came into being (Barthes, 1989; Eliade, 1986; Levi-Straus, 2000).

By being included in a given reality, myths are reproduced by memory and establish a link between the past and the present. Therefore, they have a historical characteristic, and their creation in 
organizational space can be seen as a way of establishing correct and valued behavior as opposed to unacceptable actions. Myths play an important role in forming organizational culture because they are rapidly created and easily perceived by members of the organization (Fleury \& Fisher, 1996). The author also states that "an attempt to interpret the myth is crucial in order to understand the symbolic universe both as an integrating element that defines the identity of the organization and as a way of revealing the mechanisms of power within the organization”. Thus the myth may play a political role in organizations. When expressing ideal, socially acceptable behavior, the myth strengthens the idea of cooperation and organizational stability. In other words, myths justify and maintain values subjacent to political interests; they mediate contradictions between expected behavior and perceived behavior and legitimize power relations (Rodrigues, 1997).

In organizations, the myth constructed around their foundation revives the image of the founders, heroes and charismatic leaders and keeps them alive (Deal \& Kennedy, 1982). Freitas (1991) states that the world vision of the founder of a company has considerable influence on the formation of the organizational culture. According to this author, the values, ideas and world vision of the founder leave their mark on the culture, and serve as a reference for individual and collective action. The narrative constructed around the creation of an organization can be seen as an expression that comes close to the notion of foundation myth by Chauí (2000). This author claims that

the myth imposes an internal link with the past as origin, i.e., with a never-ending past that is permanently preserved in the present and never stops finding new ways of expressing itself: new languages, new values and ideas in such a way that the more it seems to be something else, the more it reproduces itself (Chauí, 2000, p. 9).

In this symbolic production, the founder of an organization, according to Fleury and Fisher (1996), plays a relevant social role because "while he holds the global conception of the project of the organization, he has the power to structure it, develop it, and weave symbolic elements that are in line with this vision”. The author also points out that because of their trajectory in organizational space, the founders take on a mythical role, stamping their world view on the organization. The time of

foundation is the imaginary past moment that is seen as the moment of origin and is kept alive and present in the course of time, i.e., the foundation seeks for something perennial (almost eternal) that lays the framework for and supports the temporal course and gives it meaning (Chaú, 2000. p. 5).

The interpretation of the meanings attributed to the death of the founder of an organization is believed to produce a unique opportunity to understand the myth constructed around the creation process. For this purpose, it is worth presenting some theories about the meanings of death, especially those of Simmel (2000) in The Metaphysics of Death. According to this author, the meanings of life and death are nothing more than two facets of the same social phenomenon and most people see death as a dark prophecy that hovers over life, but which only concerns them when it happens. Therefore, death is an exit that is closely linked to life itself. It can impinge on life from day one without it or any particle of it having to be verifiable at any moment as a reality.

By constantly seeking life, human beings walk down the road to their meeting with death. Therefore, it is not only at the last minute that people die (Rotterdan, 2000). It is the understanding of this author that man dies from the day of his birth, and only stops dying after the fact. Death should be seen as something that gives a shape and content to life (Simmel, 2000). In the words of this author, death is, for life, a factor that adorns its contents and even sets its limits.

According to Elias (2001), death can have different meanings: as a rite of passage to an afterlife that eternalizes human existence or as something that marks the end of existence. Death is not only the transition to a different form of life, the final stage of earthly evolution. It marks the end of a cycle, either as a passage to something new or simply a transmutation from the material world to the immaterial world (Kübler-Ross, 1998, 2003). In the understanding of this author, death can mean a rupture, its symbolic production anchored in the western model of life that is projected through the denial of the idea of impermanence. This interpretation has to do with the denial of one's own death. 
Consequently, death should be avoided at all costs because life, this line that extends through time, overtakes the formal limit of its end and represents the very denial of death, whose presence permeates every moment of life. In other words, people seek life to escape death. This denial served as a reference for the construction of a symbolic universe in which death took on a meaning of an accident during life, an unexpected occurrence, thus denying its contingency in the context of an existence where the ephemeral characteristic of its permanence is hidden within.

Any and every thought of death is avoided, and the phenomenon is repressed and concealed. This leads to an unexpected appeal to immortality. Thus, death would be avoided not only by the repression of its presence but also by a belief in personal immortality (others may die, but not me) (Reis, 2005). According to this author, the certainty of death leads people to rebel against it. This rebellion has materialized in the quest for immortality through the production of life-preserving techniques, construction of institutions and myths that may be, and often are, preserved in individual and collective memory.

According to Vilhena (2004, p. 103-105), death should be seen as "universal, but its manifestations and interpretations are cultural and, as a result, cannot be detached from the multifaceted works of memory, sets of values and social practices - rituals that weave a given local symbolic system.” In the understanding of this author, with the occurrence of this social phenomenon, different meanings are produced, including a sense of irreversible loss and incurable absence. Death takes on a meaning depending on the intensity of the relationship, a break from the past and the present, a painful breakup, fear and questions about the meaning of life and transcendence. In this process, according to Vilhena (2004, p. 104),

there is a hubbub of rationalities, speculations, imaginations, creativities, emotions, memories, values, utopias and desires, all presenting narratives, beliefs, practices and efficient rituals so that the living can create or even preserve their worlds of meanings, relationships and attributions. With the reality of death, a human being becomes an interpreter of history and a speculator of reality, of the dimensions and particularities of the afterlife, where another type of life may occur. Judging himself to be knowledgeable about both realities, he also becomes a legislator of relationships between both, prescribing, regulating, forbidding and encouraging beliefs and practices between the living and the dead.

Moving on, the author states that "the art of interpreting both life and death is mediated by dialogical turmoil between subjectivities, by the concreteness of social relationships, whose possibilities lie between reference points that stem from a number of cultural backgrounds" (Vilhena, 2004, pp. 104105). Thus, according to this author, the interpretation of death undergoes a process of interpreting collective meanings. This is because, in addition to the biological death of the body, death involves the production of a complex symbolic system that is permeated by different meanings that are given to the event. Thus, the meanings of death are always socially constructed and historically situated in a given culture that feeds the memory and interpretation of the event. As well as the theoretical reflections of this topic, for this study, the basics of the constructionist approach were examined in order to systematize a theoretical and methodological framework that would enable better understanding of the phenomenon.

\section{Social Constructionism and the Methodological Approach to Understanding the Meanings CONSTRUCTED AROUND THE DEATH OF THE FOUNDER}

The choice of this approach is closely related to the nature of the problem under study and the epistemological bases that guide the choices and theoretical and methodological stance of the researcher (Brito, 2000). For this study, the descriptive method of a constructionist nature was chosen (Gergen, 1985; Spink, 2004). In other words, under the assumption that organizations are socially constructed realities, this study is based on the constructionist approach, whose main authors believe 
that the members of an organization are the main actors in its construction, i.e. they suppose that they are the creators, maintainers of values, beliefs, meanings and the main transformation agents of organizational reality (Brito 2000). The theoretical conceptions of the approach seek to provide descriptions and explanations of events and management practices from the experience of the members of the organization. Therefore, it is an approach that seeks to break away from the notion of scientific neutrality and adopt a deeply engaging intellectual stance in an attempt to understand the phenomenon in question.

\section{Epistemological Foundations of the Constructionist Approach}

This approach emerged from the attempt to overcome the epistemological dichotomy (realismsubjectivism) constructed by researchers throughout the foundation of the positivist and idealist paradigms. It is therefore a focus that, according to Gergen (1985) and Spink (2004), faces the challenge to transcend the traditional subject-object dualism from a new analysis structure based on an alternative theory of the workings and potentials of human and social sciences. According to the authors, social constructionism is concerned with the processes by which people describe, explain and/or understand the world in which they live, including their own actions. Consequently, studies that are based on epistemological and ontological assumptions shift their analysis focus from social and mental structures to understanding the meanings of social actions and practices (Santos, 2005).

The constructionist stand, according to Spink (2004), was structured around the following basic principles: (a) no object can exist independent from the process of producing meaning; therefore, subject and object are social constructions that include human forms of objectification and subjectification; (b) the deference of this stance means accepting that an oscillatory movement occurs that shifts the origin of knowledge to the external world one minute and to the internal the next. In other words, there is a disparity between the internal-subjective-mind and external-objective-world; (c) on this point, discursive formation cannot be approached as an entity that is separate from the social and the practical; language is not limited to the denotative function of objects, situations or states; on the contrary, it has a performance function in discursive formation that must be considered, within this perspective, as a social practice in itself, with its own characteristics and practical consequences; (d) constructionism cannot necessarily be considered a synonym of relativism, but rather an invitation to examine and understand conventions and rules as something that is socially situated and subject to reconstruction. This approach seeks to contribute towards demystifying scientific practice, becoming a more political perspective for deconstructing the differences and forms of oppression (physical or symbolic) that permeate social and organizational life; (e) by considering knowledge of reality as something socially constructed, it is a natural assumption that the methods produce, before anything else, versions of the world which, depending on the context of their production, their socio-historical moment, may have greater or less persuasive power; (f) finally, by understanding knowledge to be a social construction that is structured in the interface of short-, mid- and long-term socio-historical contexts, social constructionism seeks to understand the meanings attributed to experiences that are derived from contexts marked by different temporalities.

To gain access to the meanings produced and the constructed significances, the notion of discursive practices of the subjects is resorted to. According to Gergen (1985), this is language in action. A dynamic and plural language marked by different voices, speech genres and interpretative content or repertoires, which are defined as reference structures employed by people in the construction of the meanings of reality (Spink, 2004). According to this author, language should be approached as a social practice that produces references for the interpretation and attribution of meanings for everyday life.

With this reasoning, the author is of the opinion that the construction of meaning in a temporal perspective, in which the historical dimension establishes a dialogue between new people and old meanings. To understand how they occur in society, it becomes necessary to investigate the interface between remaining and rupture by looking at time in three ways: long time, characterized by cultural contents that form discourse for a determined period; lived time, which may be understood as the assigning of new meanings to historical content due to experienced socialization; and short time, 
which is the time of a happening or the moment that enables people to understand the production of meanings. This means breaking away from the habitual in order to allow for the construction of meanings attributed to the events of a given reality. Thus, according to Spink (2004), in the interconnection of these three times there is the concomitant presence of the old and the new, remaining and rupture, delimiting how the production of meanings is processed and how meanings circulate within the organization. This is the theoretical and methodological framework for this study in order to understand the death of the founder.

In this analytical process, people are seen as the builders of social relationships, i.e., there is a recurrence of social relationship games, symbolic exchanges, psychosocial constructions that promote the production of meanings that can be understood through discourse analysis. According to Corrêa and Carrieri (2004), discourse is a way in which people express their view of the world, their subjectivity, comprising a set of assumptions that mark their conceptions and guide their actions. Therefore, discourse should be viewed and analyzed as part of a network of social relationships. It is a discursive production which includes not only systems of values, reasoning, justifications, explanations, desirable and undesirable behavior, but also the interpretations, meanings constructed around the myths, stories and other constructive elements of organizational reality and culture.

Therefore, the assumption for this study is that meanings are not in language as materiality, but rather in the discourse that makes language the mechanism of mediation and the construction of reality (Rasera \& Japur, 2001; Spink, 2004). According to Spink (2004), the understanding of meanings, from a constructionist viewpoint, requires language to be taken as a social practice and therefore as the product and producer of people's actions.

\section{Procedures of Collection and Analysis of Meanings of the Death of the Founder}

When seeking to unravel and understand the meanings produced by different actors concerning the death of the founder, the researchers sought to: (a) make their interpretation by taking the point of view of the different organizational actors as a reference; (b) focus their attention on the forms of expression and language because this was how access was gained to the meanings produced by the actors when interviewed; (c) interact with the informers, seeking to capture their logic when interpreting and the meanings they produced for the phenomenon; and (d) not use the deductive research protocol, thereby avoiding a priori the formulation of any hypothesis and application of a pre-conceived theoretical model. However, on the contrary, based on the theoretical input and field research, an effort was made to reconstruct their interpretation by analyzing the discursive production of the members of the university center in question. From now on, this organization will be referred to as UNICENTRO.

Therefore, the nature of this phenomenon, in addition to contributing to the definition of the exploratory research protocol, influenced the decisions of the authors concerning the demarcation lines of their empirical study, data collection techniques and the procedures for the analysis and interpretation of the results. In other words, the nature and complexity of the phenomenon required the triangulation of data collection techniques, of which the following are of particular importance: (a) the documental analysis (analysis of local and statewide newspapers, information available on the corporate site, internal communications, the biography of the founder and official documents defining managerial policies at UNICENTRO), which revealed some aspects of the history of the organization and of the founder; (b) interviews with 17 members of the organization (5 of the teaching staff, 5 students, 5 workers and 2 managers). These interviews were taken as discursive formations and therefore contained the meanings attributed by the organizational members concerning the death (Spink, 2004); c) non-participative observation to understand some cultural aspects (gestures, rituals, scientific events, statements by managers, photographic exhibitions) at the organization in question. The application of these different research techniques, in addition to contributing to the contextualization of the problem under study, also served as a reference to consolidate a broader and deeper view of the meanings constructed around the death of the founder (Bodgan \& Biklen, 1994; Martins, 1994). 
Following this phase of the research, during the second semester of 2005, the systematization of the information collected was begun along with the analysis of the discursive production of the interviewees. This analytical procedure involved: (a) a pre-analysis: phase of the organization, systematization of ideas and constitution of the language corpus to observe the criteria for exhaustivity, representativity, homogeneity and pertinence; (b) exploration of the language corpus and (c) interpretation, understanding and description of the results.

\section{Trajectory and Foundation Myth of the Organization and the Meanings of the Death of its FOUNDER}

The analysis and interpretation of the meanings constructed around the death of the founder require an understanding of some aspects of his life and the organization that he conceived of and founded in the nineteen sixties.

\section{Trajectory and Construction of the Foundation Myth}

The life of the founder was one of many achievements in the field of education, more specifically high school and university education in the field of human and social sciences. Born in São Luiz Gonzaga in the state of Rio Grande Sul, he was a seminarist with a solid university education in philosophy, history and psychology. He was fluent in four languages and had a deep knowledge of Latin. A convicted humanist, a cultured man with a solid religious background. This native of Rio Grande do Sul came to Lavras in February, 1957. He moved to Lavras, where he would build his teaching career and start a family, at the invitation of a priest who ran a catholic high school in the town. At this school, with close connections with the Catholic Church, he taught a number of subjects and greatly contributed to the education of the young people he was in charge of. In the early 1960s, he began to teach Portuguese, English, French, Latin, geography, history and psychology at other schools in town, and also founded two others. The founder was, according to the interviews conducted, a visionary, a determined leader, an idealist, an educator who believed in education as a social mechanism for emancipation and human achievements.

(01) “[...] He was determined, he was a hard worker. He didn't only tell others what to do; he pulled his own weight as well. So he was a worker, a dedicated person and... he didn't see any drawbacks... he had that leadership quality... because these qualities like determination, willingness to work, ability to overcome obstacles are the qualities of a leader...” (Interviewee 5).

These qualities that made the founder stand out from the crowd were determining factors when it came to establishing and running the Philosophy and Letters Faculty, which today is part of UNICENTRO. Working hard from 1963 to 1968, the founder organized the statutes, fought for resources and overcame difficulties and financial hardship. This struggle culminated in the consolidation of the project he had dreamed of. The faculty welcomed its first students on 3 March, 1969, with improvised installations and without sufficient financial resources. The library had only a few books donated by the local community and the founder himself, who was the first director. The makeshift installations were vacated and a new head office for the organization was established, where it remained until 1973. The teaching was done at the installations of three high schools in Lavras, MG. The first obstacle to be overcome was the building of its own installations. The creation and the overcoming of the initial difficulties of any business venture take on a symbolism that serve as a reference for the creation of a myth. The name of the founder became exalted and the motto of the faculty was established Pro Deo Et Homine (For God and the Human Race).

This motto was ever present in the discursive production of the interviewees. Whenever they recalled the role of the founder of the organization, they would quote it both in Latin and Portuguese. This motto was coined and always quoted by the founder in his public addresses and other everyday 
communications that helped construct a symbolic system that gives the university center a unique identity. The motto became commonplace and was widely used.

(02) "[...] and he based the whole life of, the whole life of UNICENTRO on this... on a motto that he himself created and insisted on putting here. In every room you would find a poster with this motto on it... it's a Latin expression that they translated as... This motto was there from the very beginning” (Interviewee 4).

The founder also played a leading role in the consolidation of the organization, which in 1976 underwent a restructuring process and officially became an educational foundation, which began to operate along business lines. Under the management of the founder, new courses and university extension programs were added in the fields of dentistry and physiotherapy. In 2001 the organization, under the leadership of the founder, became a university center, whose goal was to be a university recognized as a center of excellence in education. The university center now offers thirteen graduate courses (biological sciences, law, nursing, pharmacy and biochemistry, physiotherapy, dentistry, letters. mathematics, teacher training, nutrition, pedagogy, psychology and chemistry). There are also twelve post-graduate courses in a number of fields. With the foundation and expansion of UNICENTRO, different values were institutionalized, resulting in a cultural pattern that provided this organization with its own identity and served as a structure for legitimizing its actions both locally and nationwide (Eliade, 1999).

According to this author, values are confirmed with the construction of a group identity and should thus be cultivated and mystically remembered throughout history. Among the values institutionalized and cultivated by the members of the university center are commitment (dedication and responsibility), ethics (honesty, respect, truth and coherence), cooperation (knowing how to listen and team work), humanism (love your neighbor, ideals, tolerance, willingness to contribute to the teaching of human beings and dignity), entrepreneurship (creativity and innovation) and pleasure (happiness and motivation). These values are essential parts of the culture of the organization. The origin of many of these values stems from the beliefs encouraged by the founder.

The analysis of the discursive productions of the interviewees shows that the founder was not only seen as a person who saw that something had to be done and then did it efficiently. He was also seen as a person with vision, a person who had a goal and was willing to fight to achieve it, an entrepreneur who achieved something that was almost impossible. The creation and success of the institution is a recurring theme in the discursive production of the interviewees, a lonely task that was the fruit of the perseverance of the founder and his belief in the future.

(03) "[...] As soon as he got here, he saw that Lavras needed something more... He created all this here [UNICENTRO] out of nothing... it was a real struggle, a real pilgrimage... Because he started out with nothing, right? It was all a dream, a utopia, an adventure, a passion for teaching. That's how he started a higher learning institution that is prestigious today... He did it on his ownl” (Interviewee 1).

The symbolism constructed around the foundation of UNICENTRO conferred a mythological characteristic upon the vision of the founder, as he was considered capable of carrying out lonely achievements, a hero who overcame obstacles, a self-made man. "This mythological characteristic of the founder imposes an internal link with the past as origin" (Chauí, 2000, p. 9). In this symbolic production, the founder played a relevant social role while he had a global conception of the university project and exercised his power to structure and develop it, thereby helping construct the symbolic elements that permeate its culture (Fleury \& Fisher, 1996), including the foundation myth.

The evidence found in this study indicates that the time of the founding of UNICENTRO has been kept alive and present over the course of time. In other words, the foundation of the organization seems to have taken on a perennial form (almost eternal) that has been sustained over time, serving as a symbolic reference for the attribution of meanings (Chauí, 2000) to the hero figure who overcame difficulties and constructed something that would have been practically impossible without his presence.

(04) “[...] It's funny that the whole initiative was exclusively his. A lot of people gave up, a lot of people abandoned the project and he pushed the project forward and created the institution” (Interviewee 7). 
His omnipresence, his willingness to solve problems through dialogue and solidarity and his dedication to his work are all recurring themes in the discourse of the interviewees. These factors are seen as "holy" factors that structure the symbolic universe around the hero who carried out his mission single-handedly. The symbolism constructed around the figure of the founder was that of the charismatic teacher who believes in his fellow man, an exemplary figure who mirrored the social role model (Deal \& Kennedy, 1982).

(05) “[...] He gave you freedom, he delegated power to people and I think that's how he managed to build an institution that is so good [...] it was that capacity of his to believe in others...” (Interviewee 7).

The discourse analysis also shows the ability of the founder to fight and make personal sacrifices in order to make his UNICENTRO project a successful reality. His fighting spirit and ability to run a business made the founder a hero whose actions were exemplary. These actions helped institutionalize an organizational memory that served and will continue to serve as a symbolic reference for assigning a new meaning to the foundation myth (Eliade, 1999). The interpretation of some of the different aforementioned historical aspects may serve as a contextual element when it comes to understanding the collectively produced symbolic universe that arose with the death of the teacher, idealist and founder of the organization. This critical incident occurred in early 2005, when the organization was undergoing a period of expansion and growth.

\section{The Meanings of the Death of the Founder and the Symbolic Immortality of his Work}

The death of the founder caused a feeling of loss in the objective and subjective dimensions of organizational life, leading to the beginning of the construction of a new "symbolic order". In other words, the death of the founder made way for the emergence of new rationalities, speculations, imaginations, emotions, memories and values, paving the way for mythological narratives and organizational beliefs that went on to constitute a new symbolic order that will be the object of the following analyses.

The death of the founder caused a physical and symbolic absence that reproduces the feeling of loss of the hero, the guardian, he who was a role model, the great teacher who knew and valued those who worked with him. On the death of the founder, the first thing people felt was a kind of symbolic emptiness (Vilhena, 2004).

The analysis of the discourse of the subjects of this study shows that the feelings surrounding the death of the founder are deeply embedded in their lives (Simmel, 2000). According to this author, feelings toward life and death are intertwined, being facets of the same social phenomenon. Thus, the death of the founder of UNICENTRO was remembered as a loss of the charismatic leadership that was capable of constructing consensus. It was the social and symbolic death of he who produced new ideas, of the man who lived for the organization and its position in society.

(06) "And what impressed me about him was his lightness of spirit. He was proactive, an entrepreneur, an innovator and above all a man who was always thinking... Because he lit this place up with his charisma. He had impressive charisma” (Interviewee 11).

These meanings attributed to the death of the founder recur in the discourse of the interviewees as something closely tied to the deeply religious characteristics of the founder. These reproduction of the characteristics will be a determining factor in maintaining the humanist values he cultivated and which were experienced by the members of the organization.

(07) "Of course they'll do everything they can to keep this alive, they're going to try to follow in his footsteps. But it's obvious that, with time, they'll have to learn to stand on their own two feet, although they will preserve the legacy he left behind. I think that the institution needs to learn how to deal with this religious and humanist legacy he left. It's not an easy task, is it? It's not easy to bear the burden of a legacy like that”... (Interviewee 1). 
The discourse analysis of the interviewees also showed that the members of the organization collectively sought to deny the symbolic death of the founder. This denial was shown in the preservation of the memory of the hero and the reproduction of the mythology that was constructed around him and in the attempt to immortalize his work and to question the competence of his daughter to run UNICENTRO.

(08) “[...] When he died, we could see it in people’s faces. They were all asking: now what? We [...] didn’t know what to do anymore. His daughter must have suffered a lot. For her it was even worse. She lost her father and then had to deal with the fact that nobody believed in her" (Interviewee 15).

However, although the first reaction after the death of the founder was the rejection of his daughter as his successor, the members of the organization came to recognize that one of the ways of immortalizing his work was to accept his daughter as his natural replacement. Therefore, the members of the organization sought to transfer the legacy of the father to his daughter. They attempted to make the daughter the image and likeness of the father, constituting a kind of cultural renewal that reveals another dimension of the symbolic denial of the death of the founder.

(09) "[...] The daughter seems to have the same spirit as her father, the same dynamism, the same friendly nature. I think she is... Now the institution does not run the risk of going in other directions... She wants to continue her father's work, keeping this humanist Christian spirit as part of the configuration of the institution" (Interviewee 14).

This denial as a form of preserving the foundation myths carries the members of the organization back to its origins, reviewing their experiences, a kind of journey back in time to the origins of UNICENTRO (Eliade, 1986, 1999). The members of the organization symbolically seek, through the projection of the father in his daughter, to return to the past, attempting to immortalize the work of the founder, which will certainly serve as a reference for construction of the future. On this subject, the daughter is always compared with the father, and at no time were her own personal qualities referred to by the interviewees. The members of the organization came to see the daughter as the person who would carry on the work of the founder, thereby immortalizing the work and image of the hero. The attempt to preserve the myth and the symbolic denial of the death of the founder is made in the discourse through statements that nothing has changed, that the purposes of the organization will remain the same. The preservation and denial can also be seen through the exhibition of the photograph and messages of the founder. These cultural manifestations are an allusion to the symbolic eternity of the founder myth and the continuity of his work.

(10) " [...] What I notice is that they are doing everything they can to stick to the values that he [the founder] brought to the institution... at assemblies they keep saying that nothing will change, that everything will stay the same” (Interviewee 9).

The continuity of the work of the founder, as a strategy of the symbolic denial of his death, is a recurring theme in the discourse of the members of the organization. This is the continuity of the immortality of his work in a complex movement of discontinuity that, on the one hand, expresses the risk of losing the leader but, on the other hand, revitalizes his memory in a kind of eternal return that brings his history alive and gives him a legacy that is strongly mystified by the members of the organization.

\section{The Meanings of the Death of the Founder: Analytical Synthesis and Implications}

The analysis of the results of this descriptive research show that the trajectory of the life of the founder will almost always be marked by historical deeds that originate, construct and renew the construction of the organizational reality. The creation of the organization and the overcoming of its initial difficulties, as is the case with any enterprise, will serve as a reference point for the institutionalization of cultural patterns marked by different values and symbolic elements, the content of which confers a mythological characteristic to the vision of the founder. 
This mythological characteristic associated with the figure of the founder imposes an internal link with the past as origin. The evidence found in this study indicates that the moment of foundation of organizations is kept alive and present over the course of time. In other words, the myth constructed around the foundation of the organization appears in some ways to become perennial. It is sustained over time and serves as a symbolic reference for the creation and mythification of a hero who ends up, in his own unique way, carrying out a mission of a collective nature. This symbolic production helps to institutionalize the foundation myth which, even after the death of the founder, will always be remembered and relived by the members of the organization.

By impacting on the objective and subjective dimensions of organizational life, the death of the founder opens a space for the emergence of new rationalities, speculations, imaginations, emotions, memories and values, creating opportunities for mythological narratives and organizational beliefs that have come to constitute a new symbolic order. The death of the founder produces a physical and symbolic absence, a feeling of loss of the hero, the guardian, he who served daily as a role model and created the construction of subjectivities that give sustenance to organizational life. In this process, the organizational members collectively seek to deny the symbolic death of the founder. This denial is manifested through attempts to preserve the memory of the hero, to reproduce his mythical image and attempt to immortalize his work. This denial, as a way of preserving the foundation myth, helps to cast people's imagination back to the origins of the organization, leading to a new meaning for the experience in a kind of eternal return to the past. The attempt to preserve the foundation myth and the symbolic denial of the death of the founder are manifested through the reproduction of his values, beliefs and his idealism. This symbolization process may be linked to the foundation myth, connected to the origin of the organizational history. Therefore, these are cultural manifestations that allude to the symbolic eternity of the founder myth and the continuity of the work of the hero who founded the organization.

It may be that the reflections presented in this article could serve as a starting point for other researchers who are interested in investigating and constructing new theoretical and methodological reflections on this subject, which is absent from the theory of organizations. If this is the case, the researchers should bear in mind that the death of the founder of any organization takes on meanings that lie on the frontiers between the subjectivity of people and the organizational culture. Therefore, it is not possible to disconnect the relevance of this relationship when it comes to understanding the phenomenon, the interpretation of which requires the investigation of the network of feelings that are constructed around it in the organizational context. The death of the founder, in any organization, cannot and should not be studied as something natural to those who have lost their historical reference incorporating the figure of the hero, embellished with all his symbolism. On the contrary, the death of the founder should be investigated as a critical incident, an organizational phenomenon that marks the symbolic dimension and organizational practice. It is worth emphasizing that the analyses conducted did not examine in detail the multiple facets and possible implications of the death of the founder in terms of organizational life. Therefore, there is still much to be added from the point of view of knowledge about his phenomenon.

Therefore, other organizational studies should be developed that focus on the objective and symbolic implications of the death of the founder for other dimensions of organizational life. Longitudinal studies that examine the epistemological assumptions of social constructionism and the methodological fundamentals of historiography could provide a fresh look and help provide more methodological and theoretical detail of the results of this study, which is essentially of an exploratory nature. This could cast insight into the reflections of the death of the founder on the rupture or continuation of strategies as a social practice in family organizations. The effects of this critical incident on the reconstitution of people's subjectivity could also be observed from ethnomethodological analyses considered in the theory of the social imagination or mourning by other fields of knowledge, as in the anthropology and sociology of culture. 


\section{CONCLUSION}

The aim of this work was to investigate the meanings constructed around the death of the founder of a university center. To this end, a theoretical-methodological approach was utilized which included the notion of organizational culture, mythos and meanings of death and some reflections on social constructionism, the ontological and epistemological assumptions of which served as a reference for understanding the socially constructed meanings of the phenomenon under study. The nature and complexity of the phenomenon required the triangulation of data collection techniques (document analysis, a study of the autobiography of the founder, interviews and non-participant observation). This methodological choice enabled the contextualization of the matter in question and also generated relevant information for the interpretation of the meanings constructed around the death of the founder.

The analyses of the results of this study should be instrumental in advancing knowledge of the symbolism constructed around the death of the founder. Among these contributions, it is worth pointing out those of a theoretical and methodological nature. In this article, a foundation was systematized that included theoretical concepts produced in the environment of the anthropology and theory of organizations. This theoretical feature enabled the production of new explanations about the symbolic universe concerning the foundation myth in organizations. This systematization could serve as a reference for other Brazilian researchers who are interested in furthering, comparing or countering the evidence presented in this article, among which it is worth emphasizing evidence concerning the thesis of the university and the specificities of the phenomenon under study. In other words, although the death of the founder is a universal and recurring phenomenon, the meanings produced around it will always be the product of a given organizational culture. Therefore, it is a multifaceted symbolic property, the specificities of which overlap in the individual and collective memory, in the revered values, in the foundation myth and other cultural manifestations that weave the organizational symbolic system.

The analyses of the research results also lead to the conclusion that the death of the founder of any organization will always be marked by a network of intersubjectively constructed meanings that serve as a reference for the reproduction of the history of the organization and the heroic deeds of he who pioneered its construction. In short, the meanings of the death of the founder were found always to be socially constructed and will be historically circumscribed to a given culture, which feeds the memory and produces its own interpretations of this event.

This finding shows that researchers should be careful when setting analytical limits to their studies because the interpretation and understanding of these meanings are necessarily subjected to the reconstruction of the trajectory of the founder's life and the history of the organization he created. This stance means investigating, among other aspects, the crossings between the subjects and the symbolic dimension of organizational life and exploring in detail the connections between these two levels of analysis or the organizational experience. In this sense, it is believed that the qualitative research that resulted in this article should have made a methodological contribution.

To a certain extent, the path trodden by the authors could serve as a starting point for the development of further studies, especially concerning the adoption of the socio-constructionist approach that considers language (in its most varied forms) as a social practice.

Finally, it is worth reporting the limits and empirical implications of the field research that resulted in this article and suggest possibilities for future studies. If facing the death of the founder has been emotionally anguishing for those who lived through it, for the observers, listening to the resulting discourse was also emotionally difficult. It is worth mentioning that this critical incident requires the reconstitution of the subjectivity of the organizational members and the reordering of authority and power in the organization. This matter has not yet been the object of analysis, and is therefore an opportunity for future research. 
Among the main difficulties facing the research team, one of the most important was maintaining the necessary reflectivity to carry out the field research. It was necessary to constitute a kind of reflexive surveillance that helped to lower the intensity of emotional involvement on the part of the researchers in relation to the symbolism constructed around the death of the founder. This critical event causes profound critical ruptures between the person who died and those who continue in the organization. This process requires adjustment to the way of understanding, feeling, perceiving and reconstructing organizational daily life.

In this sense, it is hoped that this article can serve as a reference for the construction of collective practices of facing the death of the founder of organizations, especially family organizations, in which their presence and social role have been intensely relevant. The death of the founder involves experiences that cannot be foreseen or anticipated, measured or managed. Despite its universal and inevitable nature, the death of the founder will symbolically transport people to the organizational imagination. It is worth emphasizing that the management of this critical event was not among the defined goals of the authors, but rather to witness the meanings and possible symbolic developments of the death of the founder.

\section{REFERENCES}

Aktouf, O. (1993). O simbolismo e a cultura de empresa: dos abusos conceituais às lições empíricas. In J. F. Chanlat (Org.). O indivíduo nas organizações (pp. 39-80). São Paulo: Atlas.

Barthes, R. (1989). Mitologias. Rio de Janeiro: Bertrand-Brasil.

Bodgan, R. C., \& Biklen, S. K. (1994). Investigação qualitativa em educação. Lisboa: Porto Editor.

Bourdieu, P. (1991). Language and symbolic power. London: Polity Press.

Brito, M. J. (2000). Mudança e cultura organizacional: a construção social de um novo modelo de gestão de $P \& D$ na Embrapa. Tese de doutorado, Faculdade de Economia, Administração e Contabilidade, Universidade de São Paulo, São Paulo, SP, Brazil.

Carrieri, A. P. (2002). A cultura no contexto dos estudos organizacionais: breve estado da arte. Revista Organizações Rurais e Agroindustriais, 4(1), 38-50.

Chauí, M. (2000). Mito fundador e sociedade autoritária. São Paulo: Ed. Fundação Perseu Abramo.

Corrêa, A. M. H., \& Carrieri, A. P. (2004, setembro). Administrar é criar conflitos: o assédio moral degradando as relações de trabalho no Poder Judiciário. Anais do Encontro Nacional da Associação Nacional de Pós-Graduação e Pesquisa em Administração, Curitiba, PR, Brazil, 28.

Deal, T., \& Kennedy, A. A. (1982). Corporate cultures: the rites and rituals of corporate life. Reading, Massachusetts: Addison-Wesley.

Eliade, M. (1986). Mito e realidade. São Paulo: Perspectiva.

Eliade, M. (1999). O mito do eterno retorno. Lisboa: Edições 70.

Elias, N. (2001). A solidão dos moribundos. Rio de Janeiro: Jorge Zahar Ed.

Fleury, M. T. L., \& Fisher, R. M. (1996). Cultura e poder nas organizações (2a ed.). São Paulo: Atlas.

Freitas, M. E. (1991). Cultura organizacional: grandes temas em debates. Revista de Administração de Empresas, 31(2), 73-82. 
Gergen, K. J. (1985). The social constructionist movement in modern psychology. American Psychologist, 40(3), 266-275.

Jeffcutt, P. S. (1993). From interpretation to representation. In. M. Paker \& J. Hassard (Eds.), Postmodernism and organizations (pp. 25-48). London: Sage.

Jeffcutt, P. S. (1994b). From interpretation to representation in analysis organizational, postmodernism, ethnography and organizational symbolism. Organizations Studies, 15(2), 241274.

Jeffcutt, P. S. (1994a). The interpretation of organization: a contemporary analysis and critique. Journal of Management Studies, 2(31), 225-250.

Kübler-Ross, E. (1998). A roda da vida: memórias do viver e do morrer. Rio de Janeiro: Sextante.

Kübler-Ross, E. (2003). O túnel e a luz. São Paulo: Verus.

Levi-Strauss, C. L. (2000). Mito e significados: perceptivas do homem. Lisboa-Portugal: Ed. 70.

Martins, G. A. (1994). Metodologias convencionais e não-convencionais e a pesquisa em administração. Caderno de Pesquisas em Administração, 2(1), 1-6.

Rasera, E. F., \& Japur, M. (2001). Contribuições do pensamento construcionista para o estudo da prática grupal. Psicologia Reflexiva Critica, 14(1), 201-209.

Rasera, E. F., \& Japur, M. (2004). Desafios da aproximação do construcionismo social ao campo da psicoterapia. Estudos de psicologia, 9(3), 431-439.

Reis, M. C. L. G. (2005). A morte e o sentido da vida em certos mitos gregos antigos. In M. F. Oliveira de \& M. H. P. Callia (Orgs.), Reflexões sobre a morte no Brasil (pp. 17/53). São Paulo.

Rodrigues, S. B. (1997). Cultura corporativa e identidade: desinstitucionalização em empresa de telecomunicações brasileira. Revista de Administração Contemporânea, 1(2), 45-72.

Rotterdan, E. (2000). Elogio da loucura. São Paulo: Martin Claret.

Santos, H. T. M. (2005, setembro). O método qualitativo na investigação de sentidos: uma proposta multipolar para estudos organizacionais. Anais do Encontro Nacional da Associação Nacional de Pós-Graduação e Pesquisa em Administração, Brasília, DF, Brasil, 29.

Schein, E. H. (1992). Organizational culture and leardership (2th ed.). San Francisco: Jossey-Bass.

Schultz, M. (2004). On studying organizational culture: diagnosis and understanding. San Francisco: Walter Gruyter.

Simmel, G. (2000). Metafísica da morte. São Paulo: Martins Fontes.

Spink, M. J. (2004). Práticas discursivas e produção de sentidos no cotidiano: aproximações teóricas e metodológicas (3a ed.). São Paulo: Cortez.

Tavares, M. G. P. (1991). Cultura organizacional: uma abordagem antropológica da mudança. Rio de Janeiro: Qualitymark.

Vilhena, M. A. (2004). Os mortos estão vivos: traços da religiosidade brasileira. Revista de Estudos da Religião, 3(2), 103-131. 